\title{
Pelatihan Membuat Konten Edukatif untuk Media Sosial bagi Siswa SMP Muhammadiyah 4 Cipondoh Tangerang di Masa Pandemi Covid-19
}

\author{
Wininda Qusnul Khotimah¹, Vilya Dwi Agustini ${ }^{2}$, Aprilyanti Supriyadi $^{3}$ \\ 1,2,3 Universitas Muhammadiyah Prof. Dr. Hamka, Jakarta - Indonesia
}

\begin{abstract}
ABSTRAK
Pandemi Covid-19 berdampak pada proses pendidikan yang harus melakukan proses belajar jarak jauh. Kondisi itu memaksa para siswa lebih sering bersentuhan dengan telepon pintar dan internet, tidak terkecuali aktivitas menggunakan media sosial. Beberapa platform media sosial yang banyak digunakan siswa SMP Muhammadiyah 4 Cipondoh adalah Instagram dan TikTok. Intensitas berselancar di dunia maya tersebut memerlukan literasi digital untuk memberikan pemahaman yang baik tentang bermedia sosial. Salah satunya, tentang bagaimana memanfaatkan media sosial dengan membuat konten kreatif sekaligus mengedukasi. Pelatihan ini dilakukan dengan metode ceramah, diskusi, dan kaji tindak. Kegiatan dilakukan dalam jaringan (daring) menggunakan aplikasi Zoom. Para siswa diberikan penyuluhan dan pelatihan terkait literasi digital dan membuat konten edukatif. Pelatihan ini menghasilkan pemahaman dan praktik langsung membuat video edukatif melalui akun Instagram dan TikTok para siswa.
\end{abstract}

Kata Kunci: media sosial, siswa, konten edukatif, literasi, covid-19

\section{Training to Create Social Media Educational Contents for Muhammadiyah 4 Cipondoh Middle School Students during the Covid-19 Pandemic}

\begin{abstract}
The Covid-19 pandemic has impacted the education process which leads the distance learning process. This condition forces students to have more frequent contact with smartphones and the internet, including activities using social media. Several social media platforms that are mostly used by SMP Muhammadiyah 4 Cipondoh students are Instagram and TikTok. The intensity of surfing in cyberspace requires digital literacy to provide a good understanding of social media. One of them is about how to take advantage of social media by creating creative and educational content. This training is conducted using the methods of lectures, discussions, and action studies. Activities carried out in a network (online) using the Zoom application. Students are given counseling and training related to digital literacy and creating educational content. This training resulted in direct understanding and practice of making educational videos through the students' Instagram and TikTok accounts.
\end{abstract}

Keywords: social media; students; educational content; literacy; covid-19 


\section{PENDAHULUAN}

Pengguna internet di Indonesia tahun 2020 sebanyak 73,7 persen dari populasi penduduk. Jumlah itu bertambah dari tahun sebelumnya sebanyak 8,9 persen (APJII, 2020). Kenaikan ini disebabkan pandemi Covid-19 yang mewajibkan proses belajar mengajar, bekerja, dan berbagai aktifitas lainnya menggunakan internet. Berdasarkan survey APJII tersebut, empat alasan utama penggunaan internet adalah untuk mengakses media sosial, komunikasi pesan, game online, dan belanja online. Platform media sosial yang paling banyak digunakan yaitu Facebook, Instagram, Tiktok, Twitter, Whatsapp, dan Line. Para pelajar juga menggunakan media sosial untuk berbagai kegiatan, termasuk belajar secara daring, dan mencari hiburan.

Pandemi Covid-19 menjadikan para pelajar semakin dekat dengan telepon pintar dan berselancar dengan internet. Berbagai persoalan muncul seiring banyaknya remaja menggunakan media sosial, salah satunya berkaitan dengan kesopanan dan moral. Banyak orang beranggapan Internet merupakan sarana mengubah nasib. Contohnya, Briptu Norman Kamaru, prajurit polisi yang semula tidak terkenal. Tiba-tiba ia menjadi pujaan banyak orang setelah mengunggah video saat membawakan lagu India. Ketenaran membuat Norman sering diundang ke Jakarta, shooting di televisi. Akibat sering membolos dari tugas, ia dikenai sanksi. la pun rela meninggalkan kariernya di kepolisian demi mengejar mimpi menjadi entertainer. Ternyata harapan meleset. Media massa sudah tidak menyukainya. Akhirnya ia berdagang bubur (detik.com, diakses 28/12/2020).

Memperoleh ketenaran mendadak inilah yang mendorong banyak anak-anak hingga remaja aktif di media sosial. Berbagai istilah "profesi" bermunculan, seperti selebgram, youtuber, selebtwit. Profesi-profesi baru tersebut mengilhami para remaja untuk menjadikan media sosial sebagai sarana mewujudkan cita-cita. Sayangnya, belum semua remaja memahami bagaimana memanfaatkan media sosial dengan bijak. Terkait dengan itu, para pelajar SMP Muhammadiyah 4 Cipondoh membutuhkan pelatihan terkait pemanfaatan media sosial. SMP di daerah Banten tersebut didominasi oleh siswa dari kalangan ekonomi bawah hingga menengah. Hal tersebut berkaitan dengan tingkat literasi digital para siswa siswi di SMP tersebut khususnya dalam menggunakan media sosial.

Dari survei yang dilakukan oleh tim pengabdian masyarakat, para siswa SMP Muhammadiyah 4 membutuhkan pelatihan menggunakan media sosial, membuat konten yang menarik, hingga pelatihan menjadi youtuber, sehingga tim pengabdian masyarakat memutuskan mengadakan pelatihan pemanfaatan media sosial dan membuat konten edukatif bagi para pelajar tersebut. Tujuan pelatihan literasi digital itu untuk memberi pemahaman menggunakan media sosial yang baik dan benar serta bagaimana menciptakan suatu konten yang menghibur namun memiliki nilai edukatif.

\section{METODE PELAKSANAAN}

Pelaksanaan pelatihan ini, karena dilakukan pada masa pandemi Covid-19, dilakukan secara daring menggunakan aplikasi Zoom. Pelatihan dilakukan dengan metode ceramah, diskusi, dan kaji tindak. Beberapa tahapan yang dilakukan dalam pengabdian ini adalah: (1) Survei; (2) Penyuluhan; (3) Pelatihan. Survei dilakukan untuk mengetahui sejauh mana pengetahuan 
para siswa dalam bermedia sosial, sehingga memudahkan tim untuk memberikan pelatihan yang diperlukan. Survei dilakukan secara online menggunakan googleform. Tahapan penyuluhan dilakukan melalui webinar dengan aplikasi Zoom pada 17 Desember 2020.

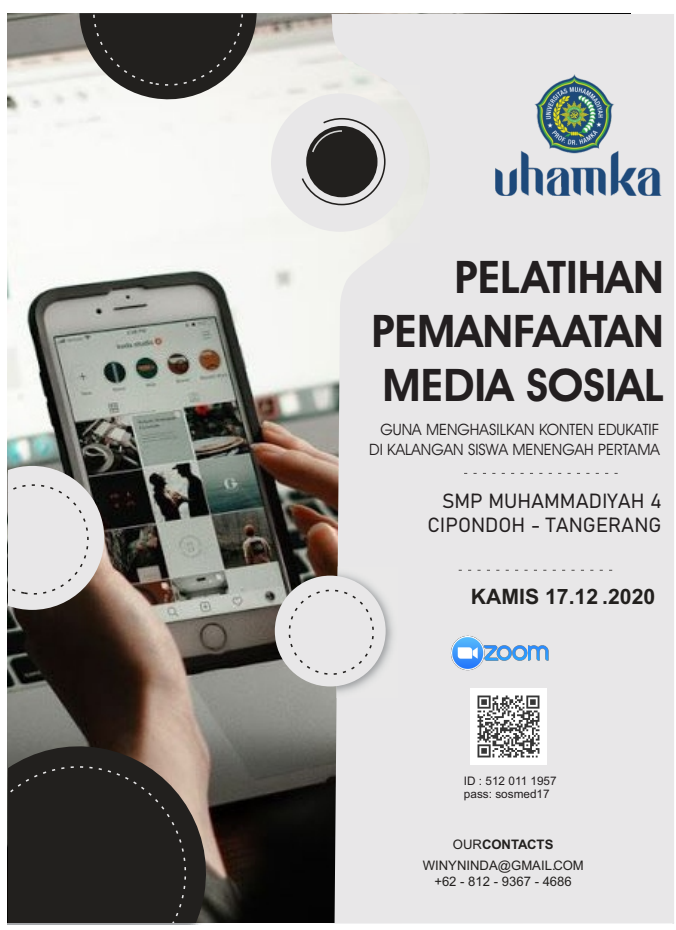

Gambar 1. Poster Kegiatan Pelatihan

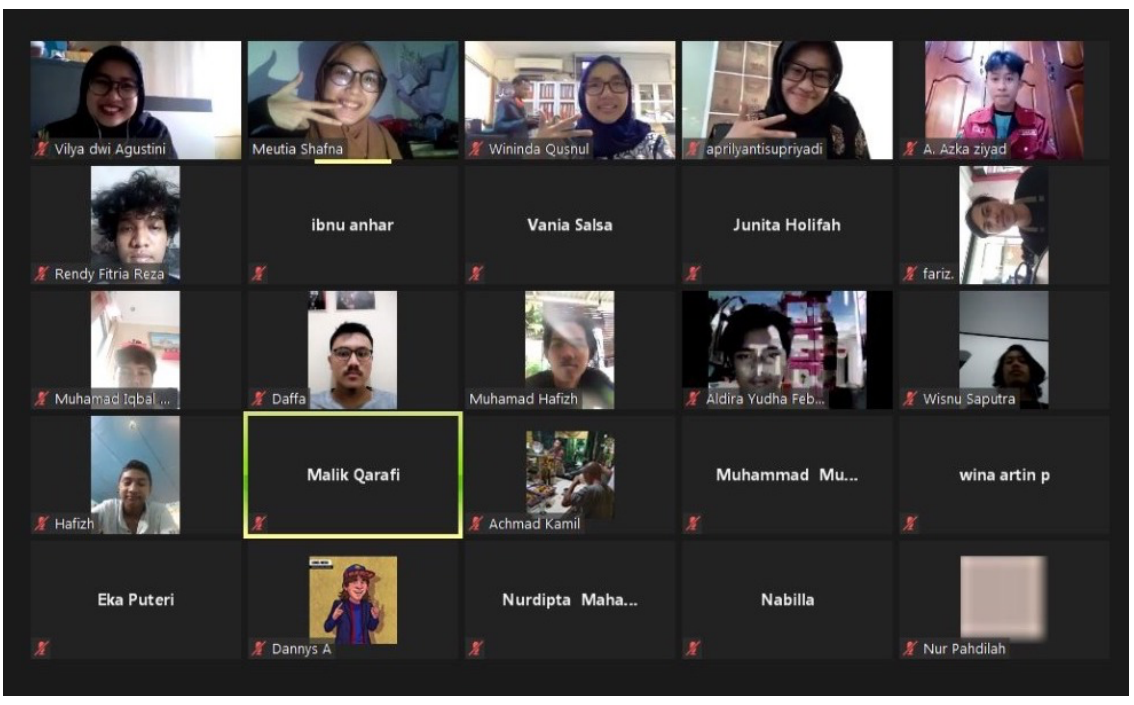

Gambar 2. Peserta Kegiatan Penyuluhan Melalui Aplikasi Zooom

Kegiatan penyuluhan dilakukan dengan memberikan pengetahuan dan pemahaman bagaimana menggunakan media sosial yang baik dan benar. Kegiatan Pelatihan dilakukan dengan mengadakan kompetisi pembuatan video edukatif menggunakan media sosial TikTok dan Instagram pada hari berikutnya.

Adapun solusi yang diberikan oleh tim adalah sebagai berikut: (1) memberikan pengetahuan lebih kepada para pelajar tentang apa dan bagaimana media sosial; (2) memberikan 
pengetahuan tentang konten media sosial yang sesuai dengan usia pengguna; (3) memberikan pengetahuan tentang tata cara membuat konten yang menginspirasi bagi sesama di media sosial.

\section{HASIL DAN PEMBAHASAN}

Membuat konten edukatif melalui media sosial dipilih sebagai objek kegiatan ini, karena sebelum pandemi Covid-19 proses pembelajaran dilakukan secara langsung dan bertatap muka. Selama pandemi, semua kegiatan pembelajaran dilakukan secara daring atau online, sehingga para pelajar SMP Muhammadiyah 4 Cipondoh lebih sering menggunakan telepon pintar dan internet, tidak terkecuali untuk mengakses media sosial.

Berdasarkan metode pelatihan yang dilakukan, beberapa temuan yang didapatkan dalam pelatihan tersebut adalah sebagai berikut:

Sebanyak 63 persen siswa-siswi kelas tujuh dan delapan SMP Muhammadiyah 4 Cipondoh yang mengikuti pelatihan memiliki akun media sosial whatsapp,dan 22 persen memiliki akun Instagram, kemudian TikTok. Hasil survei tersebut digambarkan dalam Diagram 1:
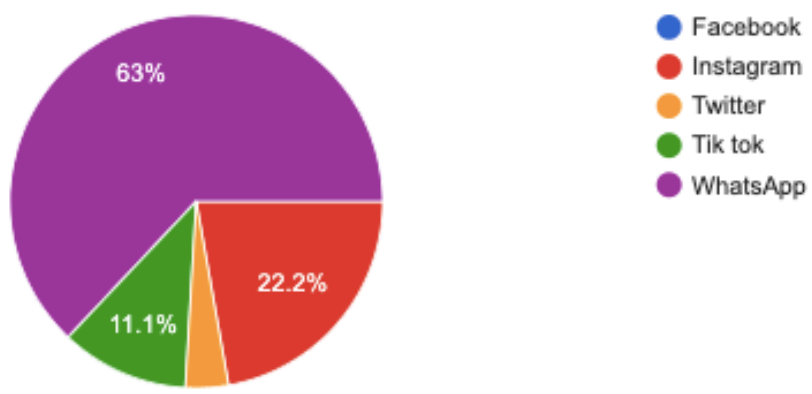

Diagram 1. Media Sosial milik Siswa SMP Muhammadiyah 4 Cipondoh

Whatsapp menjadi aplikasi yang paling banyak dimiliki dan hampir seluruh siswa menggunakan aplikasi ini dalam kegiatan sehari-hari dan proses belajar jarak jauh. Data lain menunjukkan, para siswa SMP tersebut merasakan manfaat dari penggunaan media sosial. Dari 40 siswa yang mengikuti pelatihan, hanya 7,4\% mengatakan media sosial tidak membantu mereka dalam mendapatkan informasi terkait pelajaran di sekolah. Sebanyak 92,6\% memilih media sosial bermanfaat untuk memberikan akses mereka dalam mendapatkan informasi terkait pelajaran (Diagram 2).

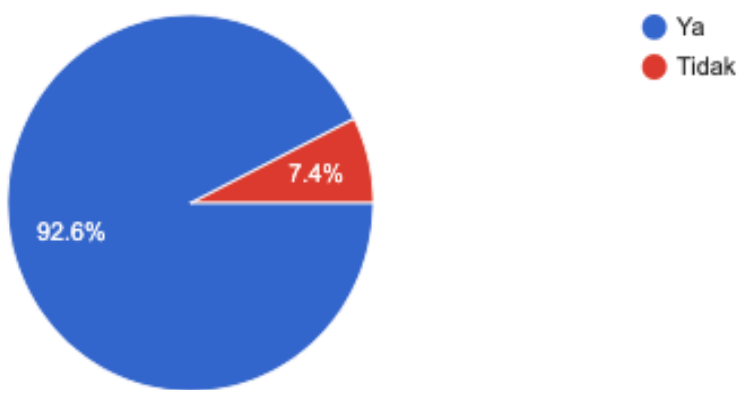

Diagram 2. Manfaat Media Sosial terkait Pelajaran Sekolah 
Melalui pelatihan ini, para siswa diberikan pengarahan dan pengetahuan baru tentang literasi digital yang diarahkan lebih khusus pada literasi media sosial. Secara umum pengertian literasi media adalah kemampuan membaca dan menulis atau disebut dengan melek media (Kurniawati, 2016). Jika dikaji, upaya membuat para siswa sekolah lebih melek media sudah ada sejak mata pelajaran TIK (Teknologi Komunikasi dan Informasi) diperkenalkan di sekolah itu.

Adanya pelajaran tersebut sebagai upaya membuat gerakan literasi lebih massive terkait teknologi digital. Pada masa sekarang, literasi juga berkembang kebutuhannya, media sosial menjadi bagian dari media digital yang paling dekat dengan para siswa, sehingga keberadaannya perlu mendapat rambu-rambu yang jelas, terkait kemampuan dan pemahaman bermedia sosial.

Pelatihan ini memberikan indikator untuk melihat bagaimana pengetahuan para siswa sebelum dan sesudah pelatihan membuat konten kreatif di media sosial tersebut diadakan.

Tabel 1. Indikator Keberhasilan Kegiatan

\begin{tabular}{|c|l|l|l|}
\hline No & \multicolumn{1}{|c|}{ Indikator } & \multicolumn{1}{|c|}{ Sebelum Pelatihan } & \multicolumn{1}{c|}{ Setelah Pelatihan } \\
\hline 1 & $\begin{array}{l}\text { Pengetahuan tentang } \\
\text { memanfaatkan telepon } \\
\text { pintar }\end{array}$ & $\begin{array}{l}\text { Penggunaan telepon pintar untuk } \\
\text { hiburan dan proses belajar jarak jauh }\end{array}$ & $\begin{array}{l}\text { Telepon pintar digunakan } \\
\text { untuk mencari informasi dan } \\
\text { berbagi informasi terkait } \\
\text { pelajaran }\end{array}$ \\
\hline 2 & $\begin{array}{l}\text { Pengetahuan tentang } \\
\text { pemanfaatan media sosial }\end{array}$ & $\begin{array}{l}\text { Penggunaan media sosial sebagai } \\
\text { sarana hiburan dan mencari teman }\end{array}$ & $\begin{array}{l}\text { Media sosial dapat digunakan } \\
\text { sebagai media penunjang } \\
\text { kegiatan belajar. }\end{array}$ \\
\hline 3 & $\begin{array}{l}\text { Kemampuan dalam } \\
\text { membuat konten di } \\
\text { media sosial }\end{array}$ & $\begin{array}{l}\text { Tidak mengetahui bagaimana konten } \\
\text { yang edukatif sekaligus menghibur }\end{array}$ & $\begin{array}{l}\text { Dapat membuat konten } \\
\text { edukatif dan kreatif } \\
\text { menggunakan media sosial } \\
\text { yang mereka miliki. }\end{array}$ \\
\hline
\end{tabular}

Literasi media sosial menjadi hal baru yang didapatkan oleh para siswa SMP Muhammadiyah 4 Cipondoh. Para siswa menjadi lebih peduli dalam memposting konten yang bermanfaat. Tidak hanya itu, pelatihan ini juga memberikan penyuluhan mengenai dampak baik dan buruk pemanfaatan media sosial. Kehadiran media sosial sangat membantu namun dapat berdampak negatif jika tidak ada buku manualnya. Itulah alasannya, pelatihan ini berfungsi sebagai buku panduan manual dalam penggunaan media sosial bagi para siswa. Dalam panduannya, tim memberikan penyuluhan terkait delapan elemen penting dalam pengembangan literasi digital (Belshaw, 2012), meliputi:

(1) Kultural, siswa diberikan penjelasan mengenai pemahaman ragam konteks pengguna dunia digital; (2) Kognitif, para siswa diberikan informasi terkait penilaian konten yang positif dan negatif; (3) Konstruktif, para siswa diajak berdiskusi tentang konten yang aktual; (4) Komunikatif, penyampaian informasi kepada siswa tentang memahami kinerja jejaring dan komunikasi di dunia digital; (5) Kepercayaan diri yang bertanggung jawab, para siswa dibekali konsep kepercayaan diri untuk membuat konten kreatif tetapi penuh rasa tanggung jawab; (6) Kreatif, pemahaman tentang melakukan hal baru dengan cara baru; (7) Kritis dalam menyikapi konten, pemahaman tentang daya kritis sebagai bentuk dari literasi digital yang merupakan kecakapan hidup; (8) Bertanggung jawab secara sosial, segala hal yang diunggah 
dalam media sosial akan membawa konsekuensi dan harus dipahami sebagai bagian dari manfaat menggunakan media sosial.

Membuat konten edukatif menggunakan media sosial adalah upaya dalam kecakapan digital. Kemampuan literasi digital yang baik untuk para pelajar, merupakan tujuan utama diadakannya pelatihan ini. Pandemi Covid-19 juga menjadi pemicu kebosanan para siswa dengan sekolah daring, sehingga membuat konten edukatif yang kreatif melalui media sosial bisa menjadi aktivitas baru dan positif bagi mereka.

Menurut Alkalai (2004) ada lima jenis kemahiran yang mencakup dalam istilah umum literasi digital yaitu: (1) Photo-visual literacy, kemampuan membaca dan menyimpulkan informasi dari visual; (2) reproduksi literacy, kemampuan menggunakan teknologi digital untuk menciptakan karya baru; (3) percabangan literacy, kemampuan berhasil menavigasi di media non-linear di ruang digital; (4) Informasi literacy, kemampuan mencari, menemukan, menilai dan mengevaluasi secara kritis informasi yang ditemukan di web; (5) sosio-emosional literacy, mengacu pada aspek-aspek sosial dan emosional, apakah itu mungkin melalui sosialisasi, dan berkolaborasi atau hanya mengonsumsi konten.

Melalui pelatihan literasi media sosial ini, diharapkan mampu memberikan solusi di dunia Pendidikan Sekolah Menengah. Media sosial bukan hanya untuk sarana bersosialisasi, tetapi lebih dari itu. Dengan adanya penyuluhan ini, lima kemahiran tersebut menjadi hal penting yang harus dimiliki oleh para siswa SMP Muhammadiyah 4 Cipondoh.

Melalui survei yang dilakukan oleh tim, ada beberapa hal penting yang didapatkan dalam pelatihan ini. Para siswa merasa sangat terbantu sehingga lebih berhati-hati dalam memanfaatkan media sosialnya. Para siswa diperkenankan untuk terlibat aktif berinteraksi dengan teknologi sehingga memberikan stimulasi pengembangan kemampuan problem solving, kreativitas, dan inovasi dalam bidang teknologi. Dengan demikian, pendidikan teknologi dan literasi digital yang diberikan secara proporsional, dapat mengembangkan keterampilan bermedia sosial bagi para siswa (Chandra dan Rustaman, 2009).

\section{SIMPULAN}

Dari pelatihan pengabdian masyarakat dengan tema menghasilkan konten kreatif melalui media sosial di masa pandemi Covid-19 di kalangan siswa SMP Muhammadiyah 4 Cipondoh, kendala utama yang dihadapi para siswa ialah seringnya menggunakan telepon pintar sebagai alat belajar jarak jauh selama pandemi. Media sosial yang dimiliki hanya digunakan sebagai sarana hiburan dan menambah pertemanan saja. Paparan media digital tersebut perlu didampingi dengan pengetahuan literasi media sosial yang cukup. Oleh karena itu, pelatihan ini sangat diperlukan oleh siswa SMP Muhammadiyah 4 Cipondoh agar lebih paham dan meningkatkan kreatifitas mereka terkait pembuatan konten di media sosial. 


\section{DAFTAR PUSTAKA}

APJII. (2020). Infografis Penetrasi \& Perilaku Pengguna Internet Indonesia 2020. Jakarta: Asosiasi Penyelenggara Jasa Internet Indonesia.

Belshaw, D. A. (2012). What is' digital literacy'?: a pragmatic investigation, Doctoral dissertation, Durham University.

Chandra, D.T.,Rustaman, N.(2009). Perkembangan Pendidikan Teknologi sebagai Suatu Inovasi Pembelajaran pada Pendidikan Dasar di Indonesia. Jurnal Pengajaran MIPA 14, 37-50.

Eshet, A. (2004). The Overarching Element for Successful Tecnology Integratiton, Springer International Publishing

Kurniawati, J., Baroroh, S. (2016). Literasi Media Digital Mahasiswa Universitas Muhammadiyah Bengkulu. JKM, Vol. 8 (2).

News.detik.com/berita/d-2685843/kisah-hidup-norman-pelajaran-berharga-bagi-anggotapolri. Diakses 28/12/2020. 